\title{
JAZYKOVÉ PREJAVY V HOVORENÝCH MÉDIÁCH VO VOJVODINE*
}

V predloženej práci budeme analyzovat' materiál, ktorý sme zaznamenali vo vysielaniach Rádia Nový Sad, Nového rádia Petrovec a vo vysielaniach Televízie Nový Sad v slovenskom jazyku. Budeme analyzovat' jazyk novinárov a moderátorov, ako aj prejavy ich spolubesedníkov. V spomenutých médiách vo väčšine prípadov sú všetci zamestnanci súčasne aj novinári, aj moderátori. Texty, ktoré sú odvysielané, sú zväčša vopred pripravené, čo určite vplýva na kvalitu prejavov. Len málo prejavov vzniká spontánne, najčastejšie mimo štúdia a v teréne, ked' vysielanie nie je vopred pripravené. V práci budeme analyzovat' prejavy novinárov a moderátorov, vplyv srbského jazyka a nárečia na lexikálnu, fonologickú a morfologickú rovinu. Budeme si všímat’ a analyzovat' porušovanie noriem výslovnostného, interpretačného a fonetického rázu. Moderátori a novinári sa dopúštajú väčšieho množstva chýb v uvol’nenej atmosfére, ked' vedú rozhovor. Nespisovné a srbské slová sa navyšujú aj v prípade, ked’ ide o spontánny typ rozhovoru. Jednotlivé javy sa pokúsime ozrejmit' z hl'adiska interferencie a vplyvu nárečia, ale aj z hl'adiska pravidiel skloňovania a časovania v spisovnom jazyku. Poukážeme na nenáležité tvary a pády. Rovnako tak aj na preberanie slov zo srbského jazyka a ich zarad'ovanie do prejavov realizovaných po slovensky.

Klúčové slová: médiá, spisovná podoba jazyka, nárečie, srbský jazyk, interferencia.

In the present work we analyze the material that we observed in the broadcasts of Rádio Nový Sad, Rádio Petrovec and in the broadcasts in Slovak Televízia Nový Sad. We will analyze the language of journalists and hosts as well as the speech of their collocutors. In the mentioned media, most of the journalists are also hosts. Texts that are broadcast are usually prepared in advance. That certainly affects the quality of speech. Few manifestations occur spontaneously, most often outside the studio and in the field, when the broadcast is not prepared in advance. In this work we analyze the speech of journalists and hosts, the influence of the Serbian language and dialect on the lexical, phonological and morphological levels. We notice and analyze the violation of norms of pronunciation, interpretation and phonetics. Errors increase in a relaxed environment when the host conducts an interview, and in addition, nonstandard and Serbian words increase when it comes to a spontaneous type of interview. We try to clarify the individual phenomena in terms of the interference and influence of the dialect, but also in terms of the rules of declension and tense formation in the written language. We point out inappropriate forms and declensions, as well as loanwords from the Serbian language and classify them into expressions realized in Slovak.

Keywords: media, literary form of language, dialect, Serbian language, interference.

\section{Oblast’ výskumu}

V práci budeme analyzovat' jazykové prejavy v hovorených médiách vysielaných po slovensky vo Vojvodine. Výskum v uvedenej oblasti sme realizovali za posled-

* Tento príspevok je parciálnym výsledkom v rámci republikového projektu Diskurzy menšinových jazykov, literatúr a kultúr v juhovýchodnej a strednej Európe (178017), ktorý financuje Ministerstvo osvety, vedy a technologického rozvoja Republiky Srbsko. 
ný rok. Sledovali sme vysielania Rádia Nový Sad v slovenskom jazyku, ktoré je verejným mediálnym servisom a jeho realizácia je financovaná zo štátneho rozpočtu. Rovnaká situácia týkajúca sa financovania je aj vo vysielaniach v slovenskom jazyku v Televízii Nový Sad. Ďalšie médium, ktoré bolo predmetom nášho výskumu, je program Nového rádia Petrovec, ktoré je v súkromnom vlastníctve. Nazdávame sa, že aj tieto fakty určitým spôsobom vplývajú na kvalitu vysielania z hl'adiska jazyka. Myslíme tu predovšetkým na zamestnancov, novinárov a hlásatel’ov, ktorí sú v spomenutých médiách zamestnaní. Ked’že ide o slovenskú komunitu vo vojvodinskom prostredí, môžeme konštatovat', že takmer všetci sa navzájom poznáme a komunikujeme. Dokonca, väčšina zamestnancov v skúmaných médiách ukončila štúdium bud' na Oddelení slovakistiky alebo na Oddelení žurnalistiky na Filozofickej fakulte v Novom Sade. Odkedy bolo založené Oddelenie žurnalistiky v roku 2004, každý rok sa na ňom rozhodne študovat' niekol'ko študentov zo slovenského jazykového spoločenstva. Sú to študenti hlavne z regiónov Báčka a Banát, ktorí sa potom uplatňujú bud'to v hovorených alebo tlačených médiách, najčastejšie vo svojom prostredí. Aj v Rádiu Nový Sad v redakcii vysielania po slovensky sú zamestnaní novinári a moderátori, ktorí ukončili odbor slovenský jazyk a literatúra, niektorí z nich študijný odbor žurnalistika (ide o mladších novinárov), ale niektorí študovali aj na Pedagogickej akadémii v Sombore, vysunuté oddelenie po slovensky v Báčskom Petrovci. Jedna zamestnankyňa ukončila odbor environmentalistika v Slovenskej republike. Ked’ ide o kádre v Televízii Nový Sad v redakcii vysielania po slovensky, štruktúra zamestnancov je nasledujúca: novinári a moderátori ukončili odbor slovenský jazyk a literatúra, Fakultu politických vied, Fakultu hudobnej kultúry, odbor žurnalistika. V týchto dvoch médiách zamestnanci majú ukončené vyššie alebo vysokoškolské vzdelanie. Ked' ide o vzdelanostnú štruktúru v Novom rádiu Báčsky Petrovec, konštatujeme nasledujúce: v súčasnosti sú tam zamestnaní dvaja novinári - moderátori $\mathrm{v}$ jednej osobe. Jeden $\mathrm{z}$ nich bol počas svojho celého aktívneho pracovného života zamestnaný v spomenutej ustanovizni. Má stredoškolské vzdelanie - gymnázium, dlhoročné pracovné skúsenosti a vo svojej práci sa vyzná. Druhý zamestnanec sa dostal do pracovného pomeru pred rokom, ked' sa vrátil zo Slovenskej republiky. Ide o vojvodinského Slováka (z Kysáča), ktorý určitú dobu žil na Slovensku. Sporadicky svojimi príspevkami prispievajú do vysielania aj novinári, ktorí sú na dôchodku. Ak si všimneme štruktúru zamestnancov niekol'ko rokov dozadu, môžeme konštatovat', že to boli zvyčajne študenti, ktorí si týmto spôsobom privyrábali. Po ukončení štúdia pracovali aj nad’alej v spomenutom rádiu, pokým sa im nenaskytla lepšia pracovná príležitost'. Nový rádio Petrovec vysiela na frekvencii 91,4 MHz každý deň len po slovensky. Na webovej stránke sa uvádza, že Rádio Petrovec (neskoršie bolo premenované na Nový rádio Petrovec) vysiela od 16. novembra 1997. Posledné štyri roky je v súkromnom vlastníctve. Nechceme tu jednoznačne hovorit' o vzdelanostnej úrovni jednotlivých zamestnancov, ale myslíme si, že vzdelanostná úroveň je dôležitá a vplýva na jazykovú úroveň prejavov odvysielaných v jednotlivých médiách. Samozrejme, aj pracovná skúsenost' je dôležitým ohnivkom, ktoré vplýva na kvalitu a jazykovú úroveň odvysielaných príspevkov.

\section{Doterajšie výskumy v danej oblasti}

V roku 2007 sa uskutočnil výskum vo vysielaniach verejného mediálneho servisu Nový Sad, vo vysielaniach v rozhlase a v televízii. Príspevky sú uverejnené 
v zborníku Mediji o svakodnevici. Eva Radanovićova písala o vysielaniach pre dedinu v Rádiu Nový Sad. Sústredila sa na obsah vysielania. Zmienila sa aj o televíznych vysielaniach z oblasti kultúry. Aj tu sa zamerala na obsahovú stránku spomenutých vysielaní. Autorská dvojica jazykovedcov Michal Týr a Zuzana Týrová sa venovali jazykovej stránke niektorých televíznych vysielaní po slovensky. Autori konštatujú, že na základe niekol'kých vysielaní nemožno hovorit’ o celkovej jazykovej úrovni v tomto médiu. Na základe uvedeného analyzovaného materiálu konštatujú, že novinári uplatňujú ortoepickú normu slovenského jazyka. Ani na lexikálnej, syntaktickej a štylistickej rovine nezaznamenali odchýlky. Na prejavy v médiách upriamil svoju pozornost' aj Miroslav Dudok v štúdii Slovenčina v spoločenskom diskurze. Autor uvádza, že „varietnost' slovenčiny vo Vojvodine javí sa najmä vo fonetickofonologickej a gramatickej rovine, $v$ komunikačnej, štylistickej, pragmatickej ap. sfére. Slovenský jazyk sa tu používa $\mathrm{v}$ pestrom komunikačnom spektre a jeho členitost' je výrazná“ (Dudok 2008: 55). Ďalej hovorí, že nárečová výslovnost' v tomto prostredí preniká a udomácňuje sa $\mathrm{v}$ televíznych a rozhlasových prejavoch (to potvrdil aj v súčasný výskum - poznámka autorky). Ďalej autor píše o vplyve srbského jazyka. „Nejde o kalkovanie, adaptovanie, parciálnu jazykovú citáciu. Často sa uplatňujú v prehovoroch celé fragmenty z iného (srbského) jazykového kódu bez jazykovej reinterpretácie..." (Dudok 2008: 65). Jasna Uhláriková uskutočnila výskum na tému Kultúrne obsahy v slovenských médiách vo Vojvodine (Kulturni sadržaji u slovačkim medijima u Vojvodini). Témou príspevku nebola jazyková kultúra, ale autorka sa zamerala na kultúrny okruh v televíznych, rozhlasových, tlačených a elektronických médiách. Autorka konštatuje, že v médiách boli zverejnené príspevky z rozličných sfér kultúrneho života Slovákov vo Vojvodine. Anna Makišová v príspevku Jazyková kultúra v televiznych a rozhlasových médiách po slovensky sa zamerala prevažne na ortoepickú stránku jazykových prejavov. Zborník prác Súčasná slovenčina $v$ srbských a slovenských elektronických médiách obsahuje 11 príspevkov, v ktorých sa analyzuje bežne používaný jazyk $\mathrm{v}$ mediálnej komunikačnej sfére $\mathrm{v}$ hovorených komunikátoch realizovaných $\mathrm{v}$ slovenských elektronických médiách vo Vojvodine autorov zo Slovenska a z Vojvodiny. Lubomír Kralčák v príspevku Slovenčina v srbských a slovenských elektronických médiách uvádza, že výslovnost' mäkkého „1““, ktorá je príznačná pre enklávnu slovenčinu, predstavuje prienik nárečového základu do štandardnej variety. Ďalej hovorí, že pre vojvodinský región sú príznačné špecifiká, ktoré možno hodnotit ako funkčné regionalizmy, ktoré sú pre naše prostredie nepríznakové. Lingvista Juraj Glovňa poukázal na vplyv nárečia a srbčiny na zvukovú, morfologickú, syntaktickú a lexikálnu rovinu. „V bežnom jazyku (l'udový každodenný jazyk) sa stupňuje príliv srbizmov, jazyk sa hybridizuje vo všetkých jazykových rovinách, najviac v lexike" (Glovňa 2015: 36). Marcel Olšiak porovnával hovorenú podobu slovenčiny v slovenských a srbských médiách. Slovenské televízne vysielanie v Srbsku je vždy vopred pripravené, aby sa do vysielania nedostali nespisovné slová. Upozorňuje, že treba prihliadat' na spravodajskú intonáciu. V médiách na Slovensku prevláda nadmerné tempo reči, čo st’ažuje vnímanie informácií u poslucháča. V srbských médiách tempo reči nie je až také výrazné, prihliada sa na dôraz a vetný prízvuk. Anna Marićová a Anna Margaréta Valentová sa zamerali na nenáležité jazykové formy a odchýlky od spisovnej normy v médiách vo Vojvodine. Uvádzajú odchýlky v jednotlivých jazykových rovinách. Rovnako ako aj predchádzajúci lingvista, uvádzajú vplyv nárečia a srbského jazyka na prejavy novinárov, 
hlásatel’ov a moderátorov. Zdôrazňujú, že aj občania, ktorí sa dostanú na televíznu obrazovku, by sa mali vyjadrovat' v súlade s kodifikačnou normou spisovného jazyka. Všetci autori v uvedenom zborníku sledovali jazyk a jazykové znaky, ktoré sú špecifikami vojvodinskej enklávnej slovenčiny vyplývajúcimi z tradičného nárečového základu a z kontaktu so srbčinou. Výsledok výskumu ukázal, že zdrojom najpočetnejších osobitostí je aktuálny slovensko-srbský bilingvizmus, príznačný pre absolútnu väčšinu používatel'ov slovenčiny. Rovnako tak do spisovných prejavov prenikajú tak dialektizmy, ako aj lexikálne prvky. V roku 2009 bolo médiám venované sympózium v Novom Sade, z ktorého bol uverejnený zborník prác Slovenské vojvodinské novinárstvo vo víre mediálnych dianí. Zborník je venovaný tlačeným a hovoreným médiám vo Vojvodine. V osobitnej stati v zborníku sa píše o rozhlasových a televíznych vysielaniach, a to nielen o RTV Vojvodina, ale aj o lokálnych staniciach. V niekol'kých príspevkoch si novinári spomínajú na obdobie vo svojom živote, ked' pôsobili v niektorom z médií. Len v jednom príspevku sa autor Ján Čeman okrajovo dotkol jazykovej úrovne a píše: „Jazyková úroveň tvorcov televíznych prejavov v TV NS nie je zodpovedajúca. Dôvody na takúto konštatáciu pramenia vo viacerých faktoch. Treba vediet', že vojvodinskí Slováci sú predovšetkým stredoslovenského pôvodu a že nárečia zostali v podstate zachované, takže nárečové prvky ovplyvňujú aj základ jazykovej kultúry novinárov, resp. hlásatelov" (Čeman 2009: 90). Rovnaké vročenie má aj monografia $N a$ vlnách jubilea, v ktorej Ján Širka píše o jazykových okienkach v Novosadskom rozhlase. Uvádza ukážky, ktoré boli odvysielané $\mathrm{v}$ rozhlase.

\section{Predmet výskumu}

Materiál pre výskum sme získali tak, že sme aktívne počúvali rozhlasové vysielania novosadského a petrovského rádia a sledovali televízny program Nový Sad. Jednotlivé odchýlky, ktoré sme si všimli, sme zapisovali, potom sme zozbieraný materiál klasifikovali podla jednotlivých skupín a rovín. V práci nebudeme osobitne uvádzat', z ktorého média je zaznamenaný príklad, budeme analyzovat' súhrnný zoskupený materiál. Budeme uvádzat' jednotlivé slová a ak si niektoré slovo vyžaduje kontext, budeme ho uvádzat' aj v kontexte. Vzhl'adom na to, že analyzujeme zvukový materiál, zapisovat' budeme podl'a zásad fonetickej transkripcie. Každej hláske pri zapisovaní zodpovedá jeden grafický znak. Pri analýze ortoepickej stránky sa budeme pridržiavat' zásad, ktoré sú uvedené $\mathrm{v}$ Pravidlách slovenskej výslovnosti Ábela Král'a a podl'a toho budeme aj zapisovat'.

V programe sa striedajú príspevky, ktoré sú vopred pripravené, ktoré majú textuálnu predlohu a do ktorých môžu zasiahnut jazykoví redaktori, d’alej sú tu príspevky čítané naživo, priamo v štúdiu, ktoré sú tiež vopred pripravené, t. j. napísané. Jazyková úroveň takýchto príspevkov je vyššia ako úroveň príspevkov, ktoré vznikajú so spolubesedníkmi priamo v štúdiu alebo počas telefonického rozhovoru a vysielajú sa naživo. Príspevky iného typu sú tie, ktoré boli nahrané v teréne a potom upravené v štúdiu. Do takýchto textov sa dá tiež zasahovat', aby boli na vyššej jazykovej úrovni. V jednotlivých reláciách je moderátor aj autorom príspevku. Všímali sme si jazykovú úroveň na jednotlivých rovinách jazyka. V prvom rade sme analyzovali ortoepickú rovinu, potom fonetickú, lexikálnu a morfologickú. Výsledky na jednotlivých úrovniach vyhodnocujeme v nasledujúcej časti príspevku. 


\section{Ortoepická rovina}

Správna výslovnost' je dôležitou súčast'ou ako hovorového, tak aj spisovného jazyka. Rovnako tak je dôležitou súčast'ou hovoreného jazyka spisovnej slovenčiny v mediálnej sfére, ktorá je predmetom nášho výskumu. Správna výslovnost' by sa mala uplatňovat' pri každom verejnom vystupovaní bez ohl'adu na to, o ktorej oblasti hovoríme. Každá výslovnost' je ovplyvnená prostredím, v ktorom používatel' jazyka žije, tiež jeho pôvodom, vzdelaním a aj jeho osobnost'ou. Práve v oblasti hovorených médií by sa mala dodržiavat' správna výslovnost' jednotlivých hlások, malo by sa prihliadat' na kvantitu hlások, na mäkkost' - tvrdost' jednotlivých hlások a podobne. Čo sa týka tejto oblasti, môžeme konštatovat', že novinári, resp. moderátori vo všetkých skúmaných médiách prihliadajú na aspekt výslovnosti. Vo väčšine prípadov je výslovnost' v súlade s normami spisovnej výslovnosti. Moderátori poznajú výslovnostné normy a dodržiavajú jednotlivé výslovnostné pravidlá. Ked' ide o výslovnost' samohlások, tu sme nezaznamenali väčšie odchýlky od pravidiel spisovnej výslovnosti. Konštatujeme, že novinári a hlásatelia v skúmaných médiách dodržiavajú pravidlá pri výslovnosti krátkych a dlhých samohlások. Dôležitým rozdielom medzi slovenskými krátkymi a dlhými samohláskami je rozdiel v trvaní. Kvantita hlások súvisí aj s tempom reči. Pri pomalšom tempe sa trvanie výslovnosti samohlások predlžuje a pri rýchlejšom vyslovovaní sa skracuje. Skracovanie nie je také výrazné, že by sa porušovala spisovná norma dížky samohlások. Rýchlejšie tempo reči badat'v spravodajských reláciách, ked' moderátori čítajú vopred pripravený materiál. Výraznejšie skracovanie samohlások sme zaznamenali u spolubesedníkov, teda nešlo o moderátorov a novinárov. Išlo o prejavy jednotlivcov, ktorí používajú stredoslovenské nárečia: vpl'v́vaju, ňeprinášaju, ňema, ňemaju, spievaju, zl'ich, zosnulich namiesto: vplývajú, neprinášajú, nemá, nemajú, spievajú, zlých, zosnulých. Ide prevažne o slovesá a môžeme to pokladat' za vplyv stredoslovenského nárečia. Niekedy sa dlhé samohlásky chybne skracujú, takže sú polodlhé alebo celkom krátke. Najviac sa dlhé samohlásky krátia vo viacslabičných slovách, a to v koncových slabikách, najmä ak sú v tom istom slove dve dížky: prechádzaju, nápadnymi, úlohach. Skracovanie dlhých samohlások je v spisovnej slovenčine vážna ortoepická chyba. Táto chyba môže spôsobovat' aj problémy v dorozumievaní. Rozdiel medzi krátkymi a dlhými samohláskami sa využíva funkčne, pretože dížkou samohlásky sa v slovenčine líšia slová. Také príklady, kde by nastal posun vo význame, sme nezaznamenali. Predlžovanie krátkych samohlások na miestach, kde v spisovnej slovenčine máme krátku samohlásku, sme v našom výskume zaznamenali v minimálnej miere. Išlo o ojedinelé prípady, ked' moderátor predížil výslovnost' samohlásky. Aj tieto uvedené odchýlky môžeme považovat' za vplyv nárečia (s novíma lavicámi). Druhú skupinu tvoria zámená, ktoré v stredoslovenskom nárečí majú dĺžku a potom sa ten tvar dostáva aj do spisovných prejavov nielen v médiách, ale (ako sme si všimli) aj v iných oblastiach verejného života. Sú to tvary zámen: naším (tvar datívu sg. venujeme sa naším hostkám), svojích, za námi, našich - namiesto našim, svojich, nami, našich. Predlžovanie samohlások pri slovesách: dostát', ból namiesto dostat', bol; pri príslovkách: po slovenskí, zajtrá, namiesto: po slovensky, zajtra. V jednom médiu sme si všimli aj odlišnú výslovnost' samohlásky ä v slovách mäkký, zmätok, pät', devät', napätie, väzba, svätý. V uvedenom kontexte nemôžeme hovorit' o vplyve nárečia. Podl'a pravidiel slovenskej spisovnej výslovnosti sa samohláska ä vyslovuje ako e. Aj v nárečiach vo Vojvodine (v 
stredoslovenskom a západoslovenskom type) neexistuje odlišnost' pri výslovnosti $e$ a $\ddot{a}$. Odlišnosti máme jedine v ortografii. Preto odporúčame vyslovovat' samohlásku ä rovnako ako samohlásku e. Iná výslovnost', teda tá, ktorú sme si všimli, znie neprirodzene a nemá svoje opodstatnenie. V uvedenom prípade sa to dá označit aj ako hyperkorektnost', ked' moderátor vynakladá nadmernú snahu, aby sa vyjadroval čo „,najsprávnejšie“, pričom sa dostáva do takej situácie, ked’ realizuje výslovnost’, ktorá je spisovnej výslovnosti cudzia.

Výslovnost' dvojhlások v hovorených médiách sa uskutočňuje podl’a pravidiel spisovnej výslovnosti. Jedinú odchýlku sme zaznamenali pri vyslovovaní dvojhlásky ô. Ide tak o pripravené, ako aj o nepripravené jazykové príspevky. Vo väčšine prípadov sa vyskytla v reči spolubesedníkov, ale niekol'ko príkladov sme zaznamenali aj v reči novinárov, najmä ked' išlo o vopred nepripravené príspevky, teda bol to nejaký rozhovor, ktorý vyplynul zo situácie. Namiesto dvojhlásky ô sme zaznamenali výslovnost' dlhého ó: móžem, ňemóžem, pomóžem, pójd'eme, ósmaci. V tomto kontexte ide o vplyv nárečia pri výslovnosti ó namiesto dvojhlásky ô.

Osobitnú pozornost' treba venovat' zmäkčovaniu spoluhlások d, t, l, n pred i, í, e, ia, ie, iu. Tu platia pravidlá, že v slovenských slovách nastáva zmäkčovanie, čiže uvedené spoluhlásky vyslovujeme mäkko. V našom výskume sme nezaznamenali časté odchýlky od spisovnej normy, až na výslovnost' zakončenia pri slovesách minulého času -li. O uvedenej odchýlke sme už písali (Makišová 2014: 239-240). Častejšie odchýlky od pravidiel sa vyskytujú $\mathrm{v}$ prejavoch novinárov a moderátorov pri výslovnosti cudzích slov. Ide o zmäkčovanie, ktoré je v slovách cudzieho pôvodu nenáležité. V slovenčine platí pravidlo, že v slovách cudzieho pôvodu v slabikách, ked' po d, t, l, n nasleduje i, í, e nenastáva zmäkčovanie, uvedené slabiky vyslovujeme tvrdo. Uvedené odchýlky sme zaznamenali vo všetkých skúmaných médiách: bibliografia, digitalizácia, disciplinna, el’ektronickí, gal'éria, jubil'ej, kl’’ma, s kol'egiňou, s kol'egami, literárňi, pol'emika, problém, problematika, publikácia, publikum, realizovat', reálie, republika, stabilizácia, tel'efónni zoznam, tel'evizia, zrealizovaní a d’alšie. Zmäkčovanie nastáva pod vplyvom pravidla o zmäkčovaní v slovenských slovách. Tu si treba uvedomit' pôvod slova a uplatnit' ortoepické pravidlo. Rovnako tak vel'kou pomôckou pri výslovnosti sú aj slovníky, ktorými by mala disponovat' každá redakcia. Máme na mysli výkladové slovníky, slovníky cudzích slov a najmä Pravidlá slovenskej výslovnosti. Každý novinár má možnost' overit' si pochybnosti v súvislosti s výslovnost'ou. Ak si všimneme lexémy, ktoré sa vyskytli ako odchýlky pri výslovnosti, môžeme konštatovat', že ide o lexémy, ktoré sa vyskytujú a používajú každodenne. Preto si myslíme, že treba iba to, aby každý hlásatel' a novinár dbal na svoju výslovnost'. Nemôžeme jednoznačne tvrdit', že uvedené odchýlky sa vyskytli u všetkých novinárov a moderátorov. Nazdávame sa, že dôležitý je pôvod jednotlivcov. Vo väčšine prípadov sa tento problém vyskytuje u tých, ktorí majú blízko k stredoslovenskému nárečiu. U tých, ktorí majú blízko k západoslovenskému nárečiu, je zmäkčovanie v slovách cudzieho pôvodu menej výrazné a časté. Ďalšiu odchýlku vo výslovnosti sme zaznamenali v koreni slova, ked' po tvrdých spoluhláskach $d, l$ nasleduje tvrdé y: vpliv, diňa, liže, ližičcka, plin, plitko, bl'iskat', uplinul'i. Rovnako aj tu nemôžeme jednoznačne hovorit', že sa odchýlky vyskytujú u všetkých hlásatel'ov a moderátorov. Má to súvislost's nárečím. Tí hlásatelia a moderátori, ktorí majú blízko k stredoslovenskému nárečiu, spoluhlásky d, 1 vo výslovnosti zmäkčujú. Nenáležité 
zmäkčovanie nastáva aj pri prídavných menách vo všetkých rodoch a pádoch jednotného a množného čísla, ak sa základ končí na spoluhlásky 1, n: biel'i, bíval'í, cel’ej, mal'i, obvikl'i, smel'i, smutňi, t'epl'ejšie, upl'inul'i, zl'ich, zosnul'ich a pod.

Pri výslovnosti vlastných mien cudzieho pôvodu nastávajú odchýlky vo výslovnosti, ide o nenáležité zmäkčovanie: Natália, Emília, El’ena. A naopak, tam, kde sa žiada zmäkčovanie, sme zaznamenali tvrdú výslovnost’: Vladimír, Vladimíra.

Ortoepická rovina je prepojená s fonetickou rovinou. V rámci spisovnej výslovnosti je dôležité spodobovanie spoluhlások, výslovnost' spoluhlásky v, výslovnost' spoluhláskových skupín a zdvojených spoluhlások. Pri spodobovaní spoluhlások sme nezaznamenali vel'ké odchýlky ani vo výslovnosti novinárov a moderátorov, ani vo výslovnosti spolubesedníkov. Občas sa vyskytne nedodržiavanie znelostnej asimilácie pri pomocnom slovese v tvare prítomníka pre 1. osobu množného čísla sme, pri predložke $k u$, ktorá sa spája s datívom. Zaznamenali sme zjednodušovanie spoluhláskových skupín st’ na konci slova (vplyv nárečia): sedemnác, osemnác, šesnácte. Spoluhlásku $v$ novinári a moderátori vyslovujú ako pernozubnú spoluhlásku $\mathrm{v}$ (voda, veda), ako spoluhlásku f (f̌̃etko, fták) a ako obojpernú hlásku u (praưda, prestáuka). V niektorých prípadoch sme zaznamenali vypadnutie spoluhlásky v na začiatku slova: čela, čera, čelii a pod. pod vplyvom stredoslovenského nárečia.

\section{Lexikálna rovina}

V jednej vete alebo v rozsiahlejšom súvislom texte sa vyskytujú rôzne typy chýb. Nedopatrenia sme si všimli nielen u spolubesedníkov, ale aj u novinárov. Sme toho názoru, že každý účastník rozhovoru by mal prihliadat' na spisovnú normu jazyka. Ide o verejné vystupovanie a pri každom verejnom vystupovaní by sa mala dodržiavat' spisovná norma jazyka. Niekedy sme si všimli, že na začiatku výkladu alebo rozhovoru aj spolubesedník dodržiava spisovnú normu, ale v d’alšom výklade akoby od nej upúšt’al, alebo nebol vstave sledovat' svoj výklad. Myslíme si, že vysoké vzdelanie nie je podmienkou toho, aby človek používal jazykové prostriedky, ktoré patria do spisovnej slovnej zásoby. Schopnost' používat' spisovné slová a normy slovenského jazyka vo vyjadrovaní získava každý príslušník slovenskej jazykovej menšiny už v základnej škole. Ďalej je len na každom jednotlivcovi, ako bude zvel'ad'ovat' a rozvíjat' získané vedomosti. Uvedené fakty sú pre nás náročnejšie, pretože žijeme v bilingválnom prostredí a na komunikáciu používame viacej jazykov. Má to svoje prednosti aj nedostatky. $\mathrm{K}$ negatívam radíme hlavne vplyv väčšinového jazyka na menšinový. Nastávajú rozličné odchýlky od noriem, sú to prejavy interferencie. Niekedy sa do slovenského kontextu dostávajú prebrané srbské slová, ktoré sa preberajú bud’to v srbskej podobe alebo sa určitým spôsobom prispôsobujú zákonitostiam slovenského jazyka (bez obzira, dežurana, ekipa, kto god, má veze, nabavka, nákupci, natovárat', plodored, pokreti, pratit', prikol'ica, provetravanje, skupština, sprémat' sa, stepen, strunjača, šétat', športová oprema, tačka, takmičeňia, veće a pod.). Srbské slovo sa preberá vtedy, ked' si hovoriaci nevie spomenút' na náležité slovenské slovo alebo jednoducho nepoznaná slovenský výraz. V iných prípadoch sa zasa srbské slovo natol'ko udomácnilo, používa sa tak často, že ho vnímame ako slovenské. Tu potom nastávajú odchýlky pri prenose informácií, ked' rovnako znejúce slovo v oboch jazykoch má celkom odlišný význam, ked’ niektoré slová v spomínaných jazykoch 
patria k odlišným rodom a my preberáme zaradenie do rodu pod vplyvom srbčiny (antibiotik, auto, center, diploma, gimnazija, jubilej, muzej, praxa, tempo, víza a pod.), ked' skloňujeme nesklonné slovo a pod. Vznik a výskyt týchto javov ovplyvňuje práve srbčina, ktorá je u nás väčšinovým, úradným jazykom. V tomto kontexte zohráva dôležitú úlohu jazykové povedomie jednotlivca a tiež vedomosti, ktoré si každý jednotlivec, Slovák, osvojil v základnej škole. Tu treba prihliadat’ aj na systém, pravidlá a zákonitosti srbčiny ako kontaktového jazyka, ktoré sme si takisto osvojili v rámci základného vzdelávania. Prvky týchto dvoch jazykov sa v našej komunikácii krížia a vzájomne prenikajú z jedného jazyka do druhého. Ale dobré poznatky z týchto dvoch jazykov sú dôležité práve na ich rozlíšenie, aby sme vedeli správne zaradit', čo patrí do ktorého systému.

\section{Morfologická rovina}

$\mathrm{V}$ morfologickej rovine sú príznakové posuny $\mathrm{v}$ gramatickom rode, najmä $\mathrm{v}$ cudzích slovách, ktoré sa do slovenčiny dostávajú $\mathrm{v}$ tvaroch, aké poznáme $\mathrm{v}$ srbčine: ten auto, ten muzej, tá gymnázia, tá víza, tá diplóma a pod. Často sa používa prípona -í na označenie príslušníkov jednej rodiny Kukučkoví, Spevákoví namiesto náležitej -ovci (Kukučkovci, Spevákovci), ohýbanie zarad’ujeme k životným podstatným menám mužského rodu. Výrazný vplyv nárečia máme pri ohýbaní podstatných mien ženského rodu vzoru žena (v genitíve jednotného čísla z pokrajine, bez rybe, zo škole, bez dohode, od patronážnej sestričke; ak sa podstatné mená končia na spoluhlásky k, h, ch (noha, ruka, mucha) v datíve a lokáli sg. je časté zakončenie -i (nohi, ruki, muchi) a v nominatíve a akuzatíve pl. -e (koláčike, ploche, nožíke si načim kúpit). Do genitívu pl. ženských podstatných mien preniká pádová prípona mužských podstatných mien -ov: vel'a ženov, písankov, ceruzkov a pod. V inštrumentáli množného čísla pádová prípona nadobúda kvantitu sestrámi, táškami, mačkámi. Pri podstatných menách vzoru ulica sa často používa v genitíve sg. koncové -i (do knižnici, do matici, z literárnej sút’aži, od Soni, Maji, Tani a pod.). Pri prídavných menách koncové -ie namiesto spisovného -é (detskie hry, velkie), odchýlka pri skloňovaní (s novíma). Zakončenia slovies na -uvat' namiesto -ovat' v imperfektivizačnej funkcii (degraduvat', funguvat', hlasuvat', podporuvat', prezentuvat', účinkuvat', vakcinuvat'). Výrazné je nenáležité používanie predložiek ( $z a$ desat' minút bude; knihy $z a$ žiakov; $n a$ televízii sme videli; byt' $n a$ telefóne; $z a$ mesiac bude mat' narodeniny; cestovat' $z a$ Kulpín a pod.).

\section{Záver}

Ked' porovnáme výsledky výskumu, ktoré boli zrealizované na začiatku 21. storočia (M. Týr a Z. Týrová) a v súčasnosti, na ortoepickej rovine $\mathrm{v}$ súčasnosti badat' odchýlky od spisovnej normy. Výsledky nášho výskumu ukázali, že v prejavoch moderátorov v rozhlasových a televíznych vysielaniach sa uskutočňuje zmäkčovanie spoluhlások d, t, $1, \mathrm{n}$ pred e, i, í. Menej výrazné je u novinárov a hlásatel'ov, pre ktorých je rodným nárečím západoslovenské nárečie. Mäkká výslovnost' sa uplatňuje v hláskových pozíciách najmä v slovách cudzieho pôvodu s pôvodnou tvrdou výslovnost’ou. Výrazné mäkčenie tiež evidujeme $\mathrm{v}$ tvaroch prídavných mien, ktoré zaznamenal aj Miroslav Dudok (2008: 59). Vplyv srbčiny a preberanie lexikálnych výrazových prostriedkov je v súčasnosti zretel'né. Vo vysielaniach Nového rádia Petrovec sme zaznamenali väčší 
vplyv nárečia a srbského jazyka ako vo vysielaniach rádia a televízie Nový Sad. Podl’a nášho výskumu sa dá očakávat', že srbský jazyk bude aj v budúcnosti ovplyvňovat' vyjadrovanie nielen novinárov a moderátorov, ale aj ich spolubesedníkov. Preto je na každom jednotlivcovi, aby prihliadal na úroveň svojho jazykového prejavu.

Mediálna sféra je verným obrazom hovorenej podoby slovenčiny vo Vojvodine, $v$ ktorej sa okrem dodržiavaných spisovných noriem použivajú aj nárečové prvky. Sú to prevažne archaické a regionálne prvky. Okrem nárečových prvkov tu prenikajú aj kontaktové srbizmy.

Úroveň jazykových prejavov v každodennom používaní na území Vojvodiny je na rozličnom stupni. Na jednej strane je iná situácia, ked’ ide o používanie jazyka v každodennej komunikácii a na druhej strane je zasa iné, ked’ ide o používanie jazyka v oblasti, v ktorej je profesionálnym nástrojom (v oblasti vzdelávania, v oblasti informovania, pri verejnom vystupovaní a pod.). Rádio a televízia ako médiá nie sú len prostriedkom zábavy, ich dominantou je predovšetkým spravodajstvo, informovanie o spoločensky dôležitých udalostiach. Nemáme tu na mysli len správy a spravodajské relácie, ale aj rozličné príspevky informatívneho, vecného charakteru, vysielania s kultúrnym a zábavným obsahom. Všetky relácie a príspevky rozhlasových a televíznych vysielaní v slovenskom jazyku plnia svoju dôležitú úlohu, ktorou je uplatňovanie práva úradného používania jazyka Slovákov vo Vojvodine.

Negatívny vplyv na jazykovú úroveň novinárov, moderátorov a hlásatel’ov má neustály kontakt s Neslovákmi na pracovisku (máme tu na mysli oblast' technickej služby) a neoficiálny kontakt medzi sebou (najčastejšie v nárečí). Týmto spôsobom novinári a moderátori prepájajú na pracovisku spisovnú podobu jazyka s hovorovou a nárečovou podobou a s kontaktovým srbským jazykom. K zlepšovaniu jazykovej úrovne novinárov a moderátorov by mohlo prispiet' organizovanie kurzov, ktoré by mali na starosti odborníci zo Slovenskej republiky. Kurzy takéhoto typu by sa mali usporadúvat' pravidelne, aby mladí novinári (ale aj tí skúsení) takto získané poznatky uplatňovali v praxi. Nazdávame sa, že rovnako prospešné by bolo aj vycestovanie novinárov do Slovenskej republiky. Priamy kontakt so živou rečou by prospel nielen začínajúcim novinárom, moderátorom a hlásatel'om, ale aj tým skúsenejším, $\mathrm{s}$ viacročnou pracovnou skúsenost'ou. Pre zamestnancov rozhlasu a televízie by boli takéto špecializované kurzy vel'mi prospešné. Na dodržiavanie a zvel'ad'ovanie jazykovej kultúry je vel'mi dôležitá aj sebadisciplína a dodržiavanie spisovnej normy.

\section{Citovaná literatúra}

Čeman, Ján. Úloha Televízie Vojvodiny v zachovávaní slovenskej kultúry a identity. [V:] Vladimíra Dorčová (ed.) Slovenské vojvodinské novinárstvo vo víre mediálnych dianí. Zborník príspevkov zo sympózia. Báčsky Petrovec: Slovenské vydavatel'ské centrum, Nový Sad: Národnostná rada slovenskej národnostnej menšiny, Kulpín: Asociácia slovenských novinárov, 2009, 89-92.

Dudok, Miroslav. Zachránený jazyk. Nadlak: Vydavatel'stvo Ivan Krasko, 2008.

Glovňa, J.: Súčasná vojvodinská slovenčina $\mathrm{v}$ médiách a vo verejnom styku. In: Súčasná slovenčina v srbských a slovenských elektronických médiách. Nitra: Univerzita Konštantína Filozofa v Nitre, Filozofická fakulta, 2015. s. 30 - 37.

Makišová, Anna: Jazyková kultúra v televíznych a rozhlasových médiách po slovensky. 
[V:] Ivana Žvančević Sekeruš (ed.) Susret kultura. Novi Sad: Univerzitet u Novom Sadu, Filozofski fakultet, 2014, 237-242.

Kralčák, L’ubomír (ed.) Súčasná slovenčina v srbských a slovenských elektronických médiách. Nitra: Univerzita Konštantína Filozofa v Nitre, Filozofická fakulta, 2015.

Král', Ábel. Pravidlá slovenskej výslovnosti. Martin: Matica slovenská, 2005.

Radanović, Eva. Analiza radio emisija za selo na slovačkom jeziku (,Vysielanie pre dedinu“). [V:] Dubravka Valić Nedeljković (ed.) Mediji o svakodnevici monitoring o svakodnevici Monitoring javnog servisa Vojvodine i regionalnih televizija. Novi Sad: Novosadska novinarska škola, 2007, broj 2, 96-104.

Radanović, Eva. Tv emisije iz kulture na slovačkom jeziku. [V:] Dubravka Valić Nedeljković (ed.) Mediji o svakodnevici monitoring o svakodnevici Monitoring javnog servisa Vojvodine i regionalnih televizija. Novi Sad: Novosadska novinarska škola, 2007, broj 2, 157-164.

Dorčová, Vladimíra (ed.) Slovenské vojvodinské novinárstvo vo víre mediálnych dianí. Zborník príspevkov zo sympózia. Báčsky Petrovec: Slovenské vydavatel'ské centrum, Nový Sad: Národnostná rada slovenskej národnostnej menšiny, Kulpín: Asociácia slovenských novinárov, 2009.

Širka, Ján. Jazykové okienka slovenského programu Novosadského rozhlasu v súčasnosti. [V:] Forgáč Michal (ed.) Na vlnách jubilea. Zborník príspevkov k šest'desiatemu výročiu založenia Novosadského rozhlasu a jeho Slovenskej redakcie. Báčsky Petrovec: Slovenské vydavatel'ské centrum, Nový Sad: Národnostná rada slovenskej národnostnej menšiny, Nový Sad: Rádio-televízia Nový Sad, 2009.

Tir, Mihal, Zuzana Tirova. Jezičko-stilske i izražajne karakteristike u nekim emisijama televizije Vojvodine na slovačkom jeziku. [V:] Dubravka Valić Nedeljković (ed.) Mediji o svakodnevici monitoring o svakodnevici Monitoring javnog servisa Vojvodine i regionalnih televizija. Novi Sad: Novosadska novinarska škola, 2007, broj 2, 318-326.

Uhlarik, Jasna. Kulturni sadržaji u slovačkim medijima u Vojvodini. [V:] Ljiljana Subotić, Ivana Žvančević Sekeruš (ed.) Susret kultura. Novi Sad: Univerzitet u Novom Sadu, Filozofski fakultet, 2010, 147-151.

Ana Makišova

\section{JEZIČKO IZRAŽAVANJE U GOVORENIM MEDIJIMA U VOJVODINI}

\section{Rezime}

U radu smo analizirali emisije Radio Novog Sada, Novog radija Petrovac i emisije Televizije Novi Sad na slovačkom jeziku. Analizirali smo jezičko izražavanje novinara, moderatora i njihovih sagovornika. Tekstovi koji se emituju obično se pripremaju unapred. U radu smo predstavili uticaj srpskog jezika i dijalekta, promene na fonološkom, leksičkom i morfološkom nivou. Uočili smo odstupanja od standardnog slovačkog jezika na nivou ortoepije, kod izgovora stranih reči, pojedinih oblika imenica i prideva. U radijskim i televizijskim emisijama na slovačkom jeziku uočili smo i preuzimanje pojedinih leksema iz srpskog jezika.

Ključne reči: mediji, standardni jezik, jezička norma, dijalekat, slovački jezik, srpski jezik. 